\title{
The Tempo of Dutch Tobacco Control Policy
}

This chapter considers the tempo at which the Dutch government took steps to control smoking by comparing the moment of adoption of policy measures in the Netherlands with the United Kingdom and with the rest of Europe. Before we embark on comparisons, it will be useful to define what 'tobacco control policy' is. It is not straightforward, since it refers to various actions that governments may take. Scholars (e.g., Birkland, 2011) distinguish between "types" of policy: laws, services, incentives (spending, grants, reimbursement), taxation, and persuasion (education, campaigns). These differ in effectiveness, timelines (a quick or a slow effect), cost, efficiency, flexibility, visibility, accountability, and degree of citizen choice (Levine, Peters, \& Thompson, 1990). Effective tobacco control is comprehensive in that it is a combination of many policy instruments. At its core are laws that restrict the availability of and exposure to tobacco products. Such regulations tend to become increasingly restrictive over time and are supported by various degrees of education, cessation support, incentives, and taxation.

Experts have identified elements of effective tobacco control policy by considering evidence from countries across the world (Warner \& Tam, 2012). There is international consensus that the main building blocks of comprehensive tobacco control are:

1. Restrictions on the sale of tobacco to minors

2. Health warning labels and package descriptors

M. C. Willemsen, Tobacco Control Policy in the Netherlands, Palgrave Studies in Public Health Policy Research, https://doi.org/10.1007/978-3-319-72368-6_3 
3. Ban on tobacco advertising and promotion

4. Smoke-free legislation

5. Educational programmes to raise awareness

6. Support for smoking cessation

7. Taxation of tobacco products (WHO, 2003, 2004)

Note that the first four are regulations involving lasting improvements in tobacco control, requiring a process of law making that involves formal parliamentary voting, while 5 and 6 are more dependent on the political will to set aside the needed budgets. Measures 5, 6, and 7 may be adjusted every year. The building blocks are sometimes simplified to five measures plus monitoring of tobacco use and prevention policies, and referred to as the MPOWER package (WHO, 2008).

\section{Policy Cycles}

In the previous chapter a detailed account was given of the stages that Dutch tobacco control policy has gone through. It is helpful to restructure the events according to the stages of the policy process. According to the "stages heuristics approach" (Moloughney, 2012; Sabatier, 2007), the following stages can be distinguished:

- Agenda setting (recognising a problem that requires government's attention)

- Policy formulation (considering various policy options)

- Policy adoption (making the decision)

- Policy implementation (assuring that the policy decision is carried out, and establishment of rules and procedures)

- Policy evaluation (assessing whether the policy achieved its objectives)

The stages form cycles. A policy cycle starts when the problem is put on the political agenda and ends when impact is evaluated (Moloughney, 2012). After evaluation, a new policy process starts, depending on the outcomes of the evaluation or the recognition of a new or continued problem on the agenda.

The stages heuristic approach has been criticised for its simplistic depiction of the policy process, which in reality rarely follows a linear course. A more realistic representation is that there is an ongoing process in which policymakers consider ideas, negotiate, try out, move away, and come 
back when new opportunities arise. John $(2012$, p. 20) noted that "There is no beginning and end to public policy; for the most part there is only the middle." Despite such critical comments I use the policy stages, because categorising the process into distinct stages is useful for descriptive purposes in this chapter (Moloughney, 2012).

Tobacco control policy does not change gradually or evenly, but there are periodic bursts of activity, with intermediate periods where little seems to happen. To date the Dutch government has gone through a full policy cycle four times (Table 3.1); the cycles have become shorter over time. The first one lasted for 23 years, the next two for 10 years; the latest was 7 years. There were interims of a few years when tobacco control was almost off the political agenda.

The first cycle began in 1954, when the government started to investigate the health concerns of smoking. The first choice of policy was education, and STIVORO was founded to coordinate and professionalise education. In the 1970s an ambitious policy agenda was brought to the attention of the government, but only one option, health warnings on tobacco products, was adopted and implemented, and when the rightwing Van Agt Cabinet came to power in 1977 tobacco control disappeared from the political agenda. The first policy cycle was terminated in 1977 before it could come to blossom.

Table 3.1 Tobacco control policy cycles

\begin{tabular}{|c|c|c|}
\hline Period & Policy cycle & $\begin{array}{l}\text { Accomplished policies, initiated by government } \\
\text { or parliament }\end{array}$ \\
\hline 1954-1977 & 1. Education & $\begin{array}{l}\text { - Educational programmes targeted at youth } \\
\text { - Health warnings on cigarette packs }\end{array}$ \\
\hline 1978-1980 & Interim period & \\
\hline 1981-1991 & 2. Self-regulation & $\begin{array}{l}\text { - Tobacco Act: } \\
\text { - Smoke-free public places }\end{array}$ \\
\hline 1992-1994 & Interim period & \\
\hline 1995-2005 & 3. Regulation & $\begin{array}{l}\text { - Revision of the Tobacco Act: } \\
\text { - Advertising and promotion ban } \\
\text { - Smoke-free workplaces } \\
\text { - Ban on tobacco sales to those under } 16\end{array}$ \\
\hline 2006-2007 & Interim period & \\
\hline 2007-2014 & $\begin{array}{l}\text { 4. Decentralisation and } \\
\text { shared responsibility } \\
\text { with civil society }\end{array}$ & $\begin{array}{l}\text { - Smoking ban in pubs and restaurants } \\
\text { - Reimbursement for smoking cessation } \\
\text { - Ban on tobacco sale to those under } 18\end{array}$ \\
\hline 2014-present & Interim period & \\
\hline
\end{tabular}


From 1981 until 1991 a second policy cycle emerged from proposals set out in the Interdepartementale Commissie Beperking Tabaksgebruik (Interdepartmental Committee for Reducing Tobacco Use) (ICBT) report. This was a long period in which anti-tobacco policy was successfully kept off the political agenda by the tobacco industry network, which had a strong presence in and around government. The government chose to rely on self-regulation by the industry. In this period economic interests trumped health interests. The cycle resulted in the adoption of the Tobacco Act in 1990 with smoke-free public places and ended when it was evaluated in 1991.

The third policy cycle started in 1995, when the government realised that smoking rates were still high compared to other countries and were unlikely to go down without further measures. Minister Borst gave the reduction of tobacco-related harm high priority and accomplished an important institutional shift, giving the Ministry of Health a more central role in the policy process at the expense of the Ministry of Economic Affairs. The tobacco industry became foe instead of friend. Just before the end of her term in office, Borst succeeded in getting parliament to adopt a substantial amendment to the Tobacco Act, resulting in smoke-free workplaces, a full advertising and promotion ban, and a lower age limit for the sale of tobacco. This cycle ended in 2005 when Minister Hoogervorst evaluated the government's policy and concluded that the goal of $28 \%$ smokers had been reached.

In 2007 Hoogervorst started work on a new tobacco control policy plan based on consultation with health organisations and the industry. He assessed the political viability of new measures and concluded that there was insufficient political support to achieve any of these. The process was abruptly terminated and replaced by the Nationaal Programma Tabaksontmoediging (National Programme of Tobacco Control) (NPT). His successor, Ab Klink, was occupied with securing a smoking ban in the hospitality sector, a headache "dossier" that he had inherited from previous governments. Instead of further regulation, the government continued along the path of decentralisation and sharing responsibility with civil society. The policy cycle ended in 2014 when all involved concluded that the NPT had failed. The government decided against starting a second NPT. As it has not yet committed to a new tobacco control programme, the current period must be regarded as the interim. 


\section{Adoption of Tobacco Control Policy in the Netherlands Compared with the United KinGDOM}

The United Kingdom has not always been the leader in tobacco control. Scandinavian countries like Norway already had a Tobacco Act in 1975, requiring health warnings on tobacco packs and a ban on advertising of tobacco products, and banned smoking in workplaces in 1988. For many years the Netherlands and the United Kingdom roughly had the same timing for implementation of policies, as shown in Table 3.2, which compares the coming into force of key Tobacco Acts in both countries. For many decades the United Kingdom and the Netherlands relied on voluntary agreements with the industry instead of statutory measures. Both countries had a strong tobacco industry presence.

Table 3.2 Dates of coming into force of key tobacco control policies in the Netherlands and in the United Kingdom (bold indicates fastest date)

\begin{tabular}{|c|c|c|}
\hline & Netherlands & $U K$ \\
\hline Ban on tobacco advertising on television & 1980 & 1965 \\
\hline Ban on tobacco advertising on the radio & 1980 & 1978 (voluntary) \\
\hline $\begin{array}{l}\text { "Smoking damages health" warning on cigarette } \\
\text { packs }\end{array}$ & 1982 (voluntary) & 1971 (voluntary) \\
\hline Smoking ban in public places & 1990 & 1992 (voluntary) \\
\hline Ban on tobacco advertising in cinemas & 1996 & 1986 (voluntary) \\
\hline $\begin{array}{l}\text { Removal of misleading descriptors such as "light" } \\
\text { and "mild" from cigarette packs }\end{array}$ & $2002(\mathrm{EU})$ & $2003(\mathrm{EU})$ \\
\hline $\begin{array}{l}\text { Large-text health warnings covering } 30 \% \text { of the } \\
\text { front and } 40 \% \text { of the back of cigarette packs }\end{array}$ & $2002(\mathrm{EU})$ & $2003(\mathrm{EU})$ \\
\hline $\begin{array}{l}\text { Ban on advertising and promotion (via billboards, } \\
\text { direct mail, internet) }\end{array}$ & $2002(\mathrm{EU})$ & $2003(\mathrm{EU})$ \\
\hline Ban on sales to those under 16 & 2003 & 1908,1986 \\
\hline Ban on advertising in print media & 2003 & 2003 \\
\hline Smoking ban in private workplaces & 2004 & 2007 \\
\hline Smoking ban in the hospitality sector & 2008 & 2007 \\
\hline Smoking ban in small bars & 2014 & 2007 \\
\hline Ban on sale to those under 18 & 2014 & 2008 \\
\hline Picture warnings on cigarettes packs & 2016 & 2008 \\
\hline Ban on sales through vending machines & - & 2011 \\
\hline Ban on tobacco displays in large stores & - & 2012 \\
\hline Ban on smoking in cars in the presence of children & - & 2015 \\
\hline Ban on tobacco display in small shops & - & 2015 \\
\hline
\end{tabular}

Source for United Kingdom: ASH (2013) 
The Netherlands was slow in restricting sales to minors (2003), which the United Kingdom had implemented in 1908 and reconfirmed in the 1986 Protection of Children (Tobacco) Act. The United Kingdom introduced the first voluntary health warnings on cigarette packs in 1971, much sooner than the Netherlands, but the Dutch were faster to implement smoking bans in public places and private workplaces. When the Netherlands adopted its Tobacco Act in 1988, there did not yet exist an equivalent piece of legislation in the United Kingdom. From 1999 the United Kingdom made policy either for the kingdom as a whole (tobacco advertising) or separately for devolved governments (England, Wales, Scotland, Northern Ireland), as in the case of smoking bans. In 2005 the United Kingdom still had no ban on smoking in public places. The 2006 UK Health Act governed smoking in workplaces, but its workplace smoking ban, introduced in 2007, was comprehensive. The Netherlands retained an exemption for restaurants and bars until 2008, and for small bars until 2014, and still allows separate smoking sections.

Both countries have a long history of self-regulation by the industry of advertising restrictions, with England leading the way. In the United Kingdom, the industry banned advertising on radio already in 1978 and in cinemas in 1986. However, a comprehensive advertising and promotion ban was discussed in the same year (2001) in both parliaments. By then no fewer than seven other EU countries had already adopted this regulation and, outside the EU, so had Norway, Iceland, Poland, and Hungary. ${ }^{1}$ The first European Advertising Directive stipulated that misleading descriptors such as "light" and "mild" must be removed from packages, and large health warnings became mandatory. The Netherlands was a year faster in transposing this EU directive into national law (2002) than the United Kingdom (2003).

Table 3.2 only compares the coming into force of regulative measures that involved lasting improvements in tobacco control and require a process of law making and formal voting in parliament, but not measures such as tax increases, campaigns, and smoking cessation support. In 2000, following the Smoking Kills white paper, the United Kingdom introduced smoking cessation services (Department of Health, 1998) and from that moment embarked on a different course than the Netherlands. A combination of high tobacco taxes (not included in Table 3.2), made reasonably enforceable by the United Kingdom's island status, substantial investment into smoking cessation services and awareness-raising mass media campaigns, and consistent commitment by the government to reduce 
tobacco's appeal to children through legislation, propelled the United Kingdom into the league of world leaders in tobacco control. In contrast, the allocated budget for tobacco control in the Netherlands was cut by the government, after a relatively high level of spending in the beginning of the 2000s. It went from $€ 0.93$ per capita in 2003 to $€ 0.12$ in 2012 (Heijndijk \& Willemsen, 2015). The second UK white paper published in 2010 (Department of Health, 2010) was an extension of the comprehensive UK tobacco control strategy and resulted in several measures that have not yet been taken in the Netherlands.

\section{The Netherlands Compared with Europe}

Various attempts have been made to compare countries within Europe. Studlar and Cairney (2014) looked at the pace of tobacco policy adoption in 23 countries by identifying the average year by which 24 tobacco control instruments had been adopted. The Netherlands was relatively slow, with 1994 as the median year of adoption: 1986 was the median for the 23 countries. Another attempt to compare progress across Europe was made by a group of experts in 2003 (Thyrian \& John, 2006) who drafted a 40 -item questionnaire which covered a long list of tobacco control measures that the group identified as having the most influence on smoking. Data was gathered from 142 participants from 14 EU member states to the World Conference on Tobacco or Health in Helsinki, who were asked to assess the level of tobacco control in their own country. Fourteen Dutch delegates participated. The assessment came very soon after the implementation of the amended Dutch Tobacco Act, and this was reflected in the data: the Netherlands came out higher than average, ranking just below Finland, Sweden, Ireland, and the United Kingdom. According to the 14 Dutch respondents, the Netherlands was particularly good at providing smokers with effective smoking cessation treatment (highest rank, together with the United Kingdom).

The most widely cited effort to compare the strength of tobacco control between countries in Europe was undertaken by tobacco control experts Luk Joossens and Martin Raw in 2004 (Joossens \& Raw, 2006). Their Tobacco Control Scale (TCS) is a composite scale with points allocated by a group of experts to the six tobacco policies considered most effective according to a report from the World Bank (World Bank, 2003): tobacco taxation level, smoke-free laws, public information campaigns, advertising bans, health warning labels, and cessation support (Joossens, 
2004). The scoring reflected best practice at the time the scale was developed and did not capture early interventions considered ineffective, such as self-regulation by the industry and bans on tobacco sales to minors. Data have been published for six distinct years. The Netherlands ranked 7 th (among 28 countries) in 2004,10 th $(30$ countries) in 2005,14 th $(30$ countries) in 2007,13 th ( 31 countries) in 2010,13 th (34 countries) in 2013 , and 9th (35 countries) in 2016 (Joossens \& Raw, 2017). Since 2006 the United Kingdom and Ireland have received the highest scores, mainly due to relatively high tobacco taxes and relative large budgets allocated to media campaigns and smoking cessation treatment.

Various research groups have used the TCS to study different aspects of tobacco control policy change. Nguyen, Rosenqvist, and Pekurinen (2012) created a Tobacco Control Policy Index (TCPI) based on four of the six policy components of the TCS: smoke-free laws, bans on tobacco advertising, health warnings on tobacco packaging, and smoking cessation treatment services. They recalculated the TCS scores into a composite score ranging from 0 to $100 .^{2}$ J.R. Bosdriesz, Willemsen, Stronks, and Kunst (2014) calculated TCPI scores for 11 European countries in each year from 1969 onwards. This showed that the cumulation of policy measures follows an approximate S-curve (Fig. 3.1). It also showed that the Dutch government managed to keep up with other countries in Europe, indicating that the Netherlands is neither a leader nor a laggard in tobacco

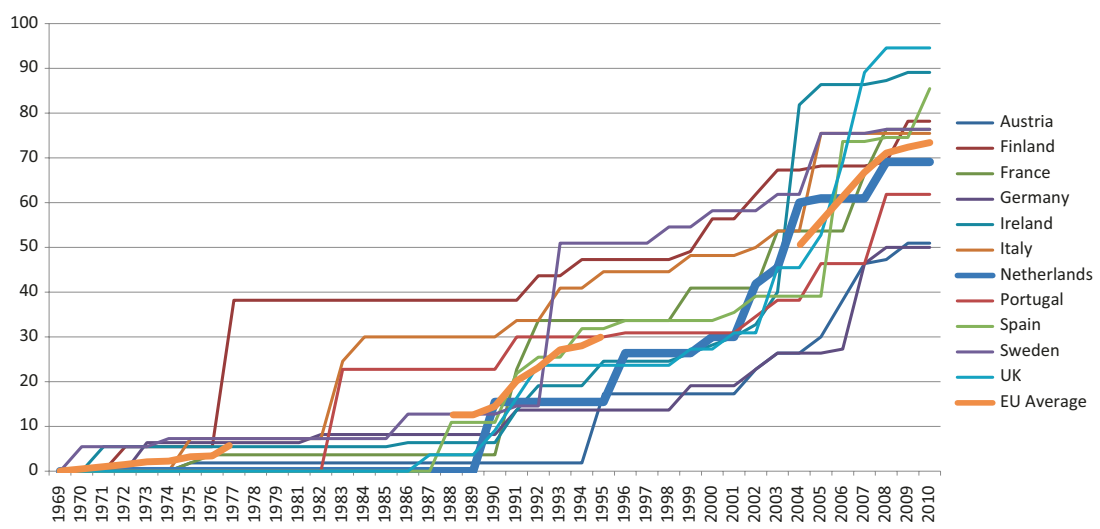

Fig. 3.1 Tobacco Control Policy Index scores between 1969 and 2010 in 11 EU countries 


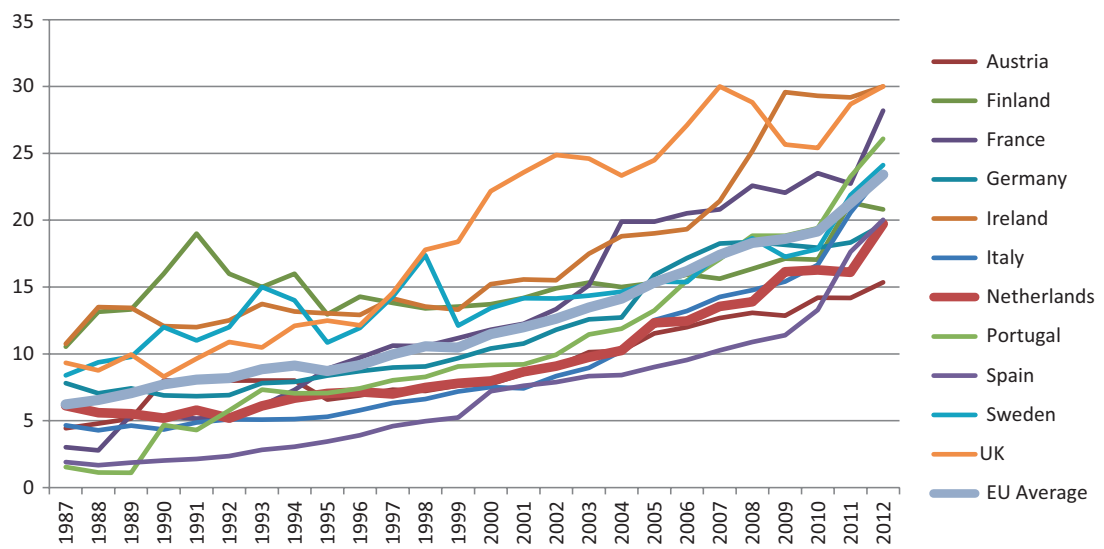

Fig. 3.2 Dates of coming into force of key tobacco control policies in the Netherlands and in the United Kingdom

control. However, it was a particularly slow starter. All countries had a zero score in 1969, but the Netherlands kept its zero the longest, after Austria. With the implementation of the Tobacco Act in 1990, the Netherlands caught up and received an average score. Between 1991 and 2002, the Netherlands again was below average, but caught up through improvements in smoking cessation treatment in the middle of the 1990s. With the adoption of the amendments to the Tobacco Act in 2002, Dutch tobacco control strength was again on a par with other countries.

With respect to tobacco taxation levels, the Netherlands can be characterised as a follower. Figure 3.2 shows TCPI scores for the level of tobacco taxation, indicated by the real price of cigarettes (Nguyen et al., 2012): this is the actual price corrected for purchasing power. Scores range from 0 to 30 , with 15 points for the highest price for a pack of Marlboro Red and 15 points for the highest rank regarding the price of a pack of cigarettes in the most popular price category. Prices are relative to the highest score (30), which was allocated to the United Kingdom in 2007 (Joossens \& Raw, 2011). The Netherlands consistently keeps its real price of cigarettes in tandem with the European average, with a price level somewhat lower than average, while the United Kingdom and Ireland have the most expensive cigarettes.

Although Dutch cigarette prices are among the highest in the EU (only France, Ireland, and the United Kingdom are higher) (Blecher, Ross, \& 
Leon, 2013), cigarettes in the Netherlands are more affordable to the average smoker than in most European countries (Blecher et al., 2013). While it took 28 minutes for the average Dutch smoker to work for one pack of cigarettes in 2010 (the same as in Germany and Belgium), it took 42 minutes in the United Kingdom and as much as 61 in Hungary (Bogdanovica, Murray, McNeill, \& Britton, 2012). Indeed, Dutch smokers are less concerned about how much money they spent on cigarettes compared with smokers in other countries (23\% compared with, e.g., $61 \%$ in France and 49\% in the United Kingdom) (ITC Project, 2015).

\section{Conclusion}

Compared to most other high-income European countries, the Dutch government was relatively late in its move to regulate tobacco. It took until 2004 to catch up with the rest of Western Europe, and currently just manages to keep up with other EU countries, neither lagging nor trying to be a leader in the field. Tobacco taxation levels are kept in line with the EU average, with real price levels just below average.

\section{Notes}

1. Proceedings II, 31 May 2001, 82-5212.

2. Changes in tobacco taxes were presented separately. The other missing component of the TCS is spending on information campaigns. This was left out in the TCPI, because reliable information on spending was not available for each year for each country.

\section{REFERENCES}

ASH. (2013). Key dates in the history of anti-tobacco campaigning. Retrieved August 29, 2014, from http://www.ash.org.uk/files/documents/ASH_741. pdf

Birkland, T. (2011). An introduction to the policy process: Theories, concepts, and models of public policy making (3rd ed.). Armonk, NY: M.E. Sharpe.

Blecher, E., Ross, H., \& Leon, M. E. (2013). Cigarette affordability in Europe. Tobacco Control, 22, e6. https://doi.org/10.1136/tobaccocontrol-2012050575

Bogdanovica, I., Murray, R., McNeill, A., \& Britton, J. (2012). Cigarette price, affordability and smoking prevalence in the European Union. Addiction, 107, 188-196. https://doi.org/10.1111/j.1360-0443.2011.03588.x 
Bosdriesz, J. R., Willemsen, M. C., Stronks, K., \& Kunst, A. E. (2014). Tobacco control policy development in the European Union-Do political factors matter? European Journal of Public Health, 25(2), 190-194. https://doi. org/10.1093/eurpub/cku197

Department of Health. (1998). Smoking kills. A white paper on tobacco. London: Department of Health.

Department of Health. (2010). A smokefree future: A comprehensive tobacco control strategy for England. London: Department of Health.

Heijndijk, S. M., \& Willemsen, M. C. (2015). Dutch tobacco control: Moving towards the right track? FCTC Shadow Report 2014. Den Haag: Alliantie Nederland Rookvrij.

ITC Project. (2015). ITC Netherlands National Report. Findings from the Wave 1 to 8 Surveys (2008-2014). Waterloo, ON, Canada: University of Waterloo.

John, P. (2012). Analyzing public policy (2nd ed.). London: Routledge.

Joossens, L. (2004). Effective tobacco control policies in 28 European countries. Brussels: ENSP.

Joossens, L., \& Raw, M. (2006). The tobacco control scale: A new scale to measure country activity. Tobacco Control, 15(3), 247-253. https://doi.org/ $10.1136 /$ tc. 2005.015347

Joossens, L., \& Raw, M. (2011). The tobacco control scale 2010 in Europe. Brussels: Association of European Cancer Leagues.

Joossens, L., \& Raw, M. (2017). The tobacco control scale 2016 in Europe. Brussels: Association of European Cancer Leagues.

Levine, C. H., Peters, B. G., \& Thompson, F. J. (1990). Public administration: Challenges, choices, consequences. Glenview, IL: Scott, Foresman/Little Brown.

Moloughney, B. (2012). The use of policy frameworks to understand public health-related processes: A literature review. Retrieved from https://www. peelregion.ca/health/library/pdf/Policy_Frameworks.PDF

Nguyen, L., Rosenqvist, G., \& Pekurinen, M. (2012). Demand for tobacco in Europe: An econometric analysis of 11 countries for the PPACTE project. Tampere: National Institute for Health and Welfare.

Sabatier, P. A. (2007). Theories of the policy process (2nd ed.). Cambridge, MA: Westview Press.

Studlar, D. T., \& Cairney, P. (2014). Conceptualizing punctuated and nonpunctuated policy change: Tobacco control in comparative perspective. International Review of Administrative Sciences, 80(3), 513-531. https://doi. org/10.1177/0020852313517997

Thyrian, J. R., \& John, U. (2006). Measuring activities in tobacco control across the EU. The MATOC. Substance Abuse Treatment, Prevention, and Policy, 1, 9. https://doi.org/10.1186/1747-597X-1-9

Warner, K. E., \& Tam, J. (2012). The impact of tobacco control research and policy: 20 years of progress. Tobacco Control, 21, 103-109. 
WHO. (2003). WHO framework convention on tobacco control. Geneva: World Health Organization.

WHO. (2004). Building blocks for tobacco control: A handbook. Geneva: World Health Organization.

WHO. (2008). MPOWER. Geneva: World Health Organisation.

World Bank. (2003). Tobacco control at a glance. Washington, DC: World Bank.

Open Access This chapter is licensed under the terms of the Creative Commons Attribution 4.0 International License (http://creativecommons.org/licenses/ by $/ 4.0 /$ ), which permits use, sharing, adaptation, distribution and reproduction in any medium or format, as long as you give appropriate credit to the original author(s) and the source, provide a link to the Creative Commons license and indicate if changes were made.

The images or other third party material in this chapter are included in the chapter's Creative Commons license, unless indicated otherwise in a credit line to the material. If material is not included in the chapter's Creative Commons license and your intended use is not permitted by statutory regulation or exceeds the permitted use, you will need to obtain permission directly from the copyright holder.

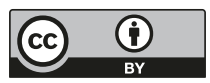

